\title{
Article \\ The Archaeal Small Heat Shock Protein Hsp17.6 Protects Proteins from Oxidative Inactivation
}

\author{
Pengfei Ma ${ }^{1,2}{ }^{\text {Jie Li }}{ }^{1}$, Lei Qi ${ }^{1}$ and Xiuzhu Dong ${ }^{1,2, *}$ \\ 1 State Key Laboratory of Microbial Resources, Institute of Microbiology, Chinese Academy of Sciences, \\ Beijing 100101, China; mapengfei006@gmail.com (P.M.); lijie824@im.ac.cn (J.L.); qil@im.ac.cn (L.Q.) \\ 2 College of Life Sciences, University of Chinese Academy of Sciences, No.19A Yuquan Road, \\ Shijingshan District, Beijing 100049, China \\ * Correspondence: dongxz@im.ac.cn; Tel.: +86-10-6480-7413
}

Citation: Ma, P.; Li, J.; Qi, L.; Dong, $X$. The Archaeal Small Heat Shock Protein Hsp17.6 Protects Proteins from Oxidative Inactivation. Int. J. Mol. Sci. 2021, 22, 2591. https:// doi.org/10.3390/ijms22052591

Academic Editor: Hideaki Itoh

Received: 20 January 2021

Accepted: 1 March 2021

Published: 4 March 2021

Publisher's Note: MDPI stays neutral with regard to jurisdictional claims in published maps and institutional affiliations.

Copyright: (c) 2021 by the authors. Licensee MDPI, Basel, Switzerland. This article is an open access article distributed under the terms and conditions of the Creative Commons Attribution (CC BY) license (https:// creativecommons.org/licenses/by/ $4.0 /)$.

\begin{abstract}
Small heat shock proteins (sHsps) are widely distributed among various types of organisms and function in preventing the irreversible aggregation of thermal denaturing proteins. Here, we report that Hsp17.6 from Methanolobus psychrophilus exhibited protection of proteins from oxidation inactivation. The overexpression of Hsp17.6 in Escherichia coli markedly increased the stationary phase cell density and survivability in $\mathrm{HClO}$ and $\mathrm{H}_{2} \mathrm{O}_{2}$. Treatments with $0.2 \mathrm{mM} \mathrm{HClO}$ or $10 \mathrm{mM} \mathrm{H}_{2} \mathrm{O}_{2}$ reduced malate dehydrogenase (MDH) activity to $57 \%$ and $77 \%$, whereas the addition of Hsp17.6 recovered the activity to $70-90 \%$ and $86-100 \%$, respectively. A similar effect for superoxide dismutase oxidation was determined for Hsp17.6. Non-reducing sodium dodecyl sulfate polyacrylamide gel electrophoresis assays determined that the Hsp17.6 addition decreased $\mathrm{H}_{2} \mathrm{O}_{2}$-caused disulfidelinking protein contents and $\mathrm{HClO}$-induced degradation of $\mathrm{MDH}$; meanwhile, Hsp17.6 protein appeared to be oxidized with increased molecular weights. Mass spectrometry identified oxygen atoms introduced into the larger Hsp17.6 molecules, mainly at the aspartate and methionine residues. Substitution of some aspartate residues reduced $\mathrm{Hsp} 17.6$ in alleviating $\mathrm{H}_{2} \mathrm{O}_{2}$ - and $\mathrm{HClO}$-caused $\mathrm{MDH}$ inactivation and in enhancing the E. coli survivability in $\mathrm{H}_{2} \mathrm{O}_{2}$ and $\mathrm{HClO}$, suggesting that the archaeal Hsp17.6 oxidation protection might depend on an "oxidant sink" effect, i.e., to consume the oxidants in environments via aspartate oxidation.
\end{abstract}

Keywords: small heat shock protein; Archaea; antioxidation; aspartate oxidation

\section{Introduction}

Small heat shock proteins (sHsps) are a family of stress-inducible protein chaperones. They possess a conserved $\alpha$-crystallin domain and have molecular weights ranging from 12 to $43 \mathrm{kDa}$ and usually form oligomers comprising 9 to 50 subunits [1-5]. sHsps are ubiquitously distributed in all types of organisms, including bacteria, archaea, and eukaryotes, and play significant roles in protecting proteins from thermal aggregation and in mitigating the irreversible aggregation of denaturing proteins.

sHsps are typically complexed with a variety of denaturing proteins in an ATPindependent manner, and act as the first line of defense against protein aggregation in response to elevated temperatures, oxidation, bacterial infection-caused inflammation, etc., and maintain protein homeostasis. Therefore, sHsps are considered as important components in the protein quality control network.

Research has determined that the human sHsps, such as Hsp20, showed multifunctional effects in cardioprotection, anti-apoptosis, inhibition amyloid formation, and possibly in carcinogenesis, cell division, and differentiation [6-11]. Bacterial sHsps also function in assisting the hosts to cope with adverse environments. Kandror and Goldberg [12] found that induced expression of the Escherichia coli sHsps was harmful and reduced the cell viability when growing at $4{ }^{\circ} \mathrm{C}$. Ferrer et al. [13] showed that overexpression of the 
Cpn60/10 gene from Oleispira antarctica, a psychrophilic bacterium from the Antarctic, increased E. coli growth rates by 3 - and 141 -fold at $15^{\circ} \mathrm{C}$ and $8{ }^{\circ} \mathrm{C}$, respectively.

The O. antarictica $\mathrm{Cpn} 60 / 10$ exhibited a higher in vitro refolding activity at lower temperatures compared with the E. coli Cpn60/10. In addition, the E. coli sHsps, IbpA/B were reported to be involved in resistance to copper-induced oxidative stress [14], and the cyanobacterial small heat-shock protein HspA was also found to play roles in enhancing the bacterial tolerance to oxidative stress and stabilization of the thylakoid membrane proteins [15]. This indicates that sHsps from different organisms could have diverse functions.

However, less is known about the archaeal sHsps, and the relevant studies are restricted to those from a few hyperthermophilic archaea, like the Sulfolobus tokodaii StHsp14.0 [16,17], the Methanocaldococcus jannaschii MjHsp16.5 [18], and the Archaeoglobus fulgidus Hsp20.2 [19]. Most studies on archaeal sHsps are focused on structural dynamics related functions. Methanolobus psychrophilus R15 is a rare cultured psychrophilic archaeon that grows optimally at $18^{\circ} \mathrm{C}$ [20]. R15 possesses three sHsps paralogs, Hsp17.6, Hsp18.9, and Hsp20.2, which exhibit 58.5\% amino acid sequence similarities, and all possess an $\alpha$-crystallin domain (Figure S1).

The three sHsps paralogs all increase transcriptions among the overall differential expressed genes in $4{ }^{\circ} \mathrm{C}$ - or $8{ }^{\circ} \mathrm{C}$ - compared with $18{ }^{\circ} \mathrm{C}$-cultured M. psychrophilus R15. In particular, the gene encoding Hsp17.6 upregulated transcription by 11-fold at lower temperatures [21,22], suggesting that these sHsps may play a role in the cold adaptation of Archaea. Of the three, Hsp17.6 is the smallest but contains the most conserved $\alpha$-crystallin domain; thus, it may possess the most related chaperone activities.

In this study, through the integration of biochemical and molecular approaches and evaluation of oxidant resistance of the sHsp heterologous expressed E. coli, we reported that Hsp17.6 from the psychrophilic archaeon M. psychrophilius R15 plays a role in the mitigation of protein oxidative inactivation and improvement of $E$. coli survivability in $\mathrm{H}_{2} \mathrm{O}_{2}$ and $\mathrm{HClO}$, likely via oxidation of its aspartate residues to consume environmental oxidants.

\section{Results}

2.1. The Small Heat Shock Proteins of M. psychrophilus Elevated the Stationary Cell Density of E. coli

M. psychrophilus possesses three sHsp paralogs, in which Mpsy_2176 encodes a $17.6 \mathrm{kDa}$ protein and was assigned as Hsp17.6; Mpsy_0075 encodes an $18.9 \mathrm{kDa}$ protein and was assigned as Hsp18.9; and Mpsy_0869 encodes a $20.2 \mathrm{kDa}$ protein and was assigned as Hsp20.2. All three possess the $\alpha$-crystallin domain (Figure S1).

To first test the canonical characteristics of the M. psychrophilus sHsps in alleviating the thermal aggregation of proteins, we heterologously expressed the three proteins with $\mathrm{N}$-terminal $6 \times$ His and SUMO fusions, purified using a Ni-affinity column, and simultaneously removed the tag with SUMO protease ULP1 to obtain tag-free proteins.

Hsp17.6, Hsp18.9, and Hsp20.2 were each mixed with either citrate synthase (CS) or luciferase at a 0-20:1 molar ratio. The three sHsps suppressing thermal aggregation of CS and luciferase were determined in dose-dependent manner based on monitoring the light scattering profiles at $360 \mathrm{~nm}$ of $45^{\circ} \mathrm{C}$-incubated protein mixtures (Figure S2). It is worth noting that Hsp17.6 exhibited much weaker activity compared with the other two, by showing a similar suppression effect at four-fold as that of Hsp18.9 and Hsp20.2 at two-fold to CS (Figure S2A), and a much weaker activity at as higher as 20-fold than that of Hsp18.9 and Hsp20.2 at two-fold to luciferase (Figure S2B).

The E. coli strains that carry one of the three M. psychrophilus Hsps or IbpA/B achieved better growth at $22{ }^{\circ} \mathrm{C}$, suggesting their roles in cold protection. Unexpectedly, the E. coli strains all obtained a higher stationary cell density compared with the vacant vector strain at 22,37 and $45^{\circ} \mathrm{C}$ (Figure S2C-E). In particular, expression of Hsp17.6 and Hsp18.9 also appeared to alleviate the $45^{\circ} \mathrm{C}$-cultured cell lysis in the stationary phase (Figure S2E). Given that more reactive oxygen species (ROS) would be accumulated in stationary cells [23,24], we hypothesize that the archaeal Hsp17.6 might have oxidation protective activity. 


\subsection{Hsp17.6 Overexpressed E. coli Gained Higher Survivability in Oxidants}

To investigate if the archaeal sHsps have an oxidation protective activity, E. coli strains that carried the encoding genes of Hsp17.6, Hsp18.9, and Hsp20.2 were tested for oxidant resistance, and the E. coli IbpA/B-expressing strain was tested in parallel. After one-hour induction of Hsps expression by isopropyl- $\beta$-d-thiogalactoside (IPTG), $0.5 \mathrm{mM} \mathrm{HClO}$ or $2 \mathrm{mM} \mathrm{H}_{2} \mathrm{O}_{2}$ was added to the mid-exponential cultures. We found that, except for the strain expressing Hsp17.6, which continued to grow at a similar rate as non-treated, those carrying other sHsps and the empty vector paused growth for a few hours after the addition of oxidants and then slowly recovered (Figure 1A,B). This suggests that Hsp17.6 could possess an oxidation protective activity. Nevertheless, it must be cautious by using the heterologous host to assay the physiological functions of sHsps, as the heterologous expressed contents (about 1-3\% total cellular proteins) may not be the same as in their native organisms.

To confirm the oxidation protective activity of Hsp17.6, an exponential culture of E. coli expressing Hsp17.6 was 10-fold diluted and spotted on Luria-Bertani (LB) plates containing $0-5 \mathrm{mM}$ of $\mathrm{HClO}$ or $\mathrm{H}_{2} \mathrm{O}_{2}$. Compared with the strain carrying the empty plasmid, which was inhibited by $0.5 \mathrm{mM} \mathrm{HClO}$, the strain expressing Hsp17.6 survived in up to $5 \mathrm{mM}$ $\mathrm{HClO}$ even at $10^{-4}$ dilution (Figure $1 \mathrm{C}$ left). Similarly, the Hsp17.6-expressing E. coli exhibited a higher tolerance to 2 and $5 \mathrm{mM} \mathrm{H}_{2} \mathrm{O}_{2}$ compared with the Hsp17.6-void strain (Figure $1 \mathrm{C}$ right); however, there was a less marked survival difference than with $\mathrm{HClO}$. These results confirm the role of Hsp17.6 in assisting bacteria to resist oxidative stress.

\subsection{Hsp17.6 Mitigated Protein Inactivation by Oxidants}

Given that oxidants, like $\mathrm{H}_{2} \mathrm{O}_{2}$ or $\mathrm{HClO}$, primarily exert oxidative damage to proteins [23,25], we tested the M. psychrophilus Hsp17.6 in protection of oxidant-caused inactivation of enzyme proteins. Malate dehydrogenase (MDH) and superoxide dismutase (SOD), which have been conventionally used in the assessment of the thermal aggregation of proteins, were used as substrates. After assessing the concentrations of $\mathrm{H}_{2} \mathrm{O}_{2}$ and $\mathrm{HClO}$ to which $\mathrm{MDH}$ and SOD were sensitive, 0.2 and $1 \mathrm{mM}$ of $\mathrm{HClO}$ and 10 and $1 \mathrm{mM}$ of $\mathrm{H}_{2} \mathrm{O}_{2}$ were used to oxidize MDH and SOD, respectively. Purified Hsp17.6 protein was mixed with the enzymes at various molar ratios and then challenged with the oxidants, and the retained enzymatic activities were assayed within 20 or $30 \mathrm{~min}$.

In parallel, Hsp18.9 and Hsp20.2 were tested for the oxidation protective activity, and SOD and MDH were also reciprocally added as controls. We determined that the addition of Hsp17.6 alleviated the oxidative inactivation of the two enzymes in a doserelated manner, as only $57 \%$ of the $\mathrm{MDH}$ activity remained in the first $5 \mathrm{~min}$ with the $0.2 \mathrm{mM} \mathrm{HClO}$ challenge; however, $\geq 90 \%$ activity was assayed in the presence of Hsp17.6 at ratios of 4-8:1 to MDH (Figure 2A). Hsp17.6 showed a higher protection on $10 \mathrm{mM}$ $\mathrm{H}_{2} \mathrm{O}_{2}$ treated $\mathrm{MDH}$ as well, as its addition at 2:1 almost completely recovered the $\mathrm{MDH}$ activity (Figure 2B).

SOD appeared to be more sensitive to the two oxidants; only $50 \%$ of the activity was retained within 1 and $5 \mathrm{~min}$ after the addition of $1 \mathrm{mM}$ of $\mathrm{HClO}$ or $\mathrm{H}_{2} \mathrm{O}_{2}$, respectively, whereas, $70 \%$ and $94 \%$ of the SOD activities were assayed within the first min when Hsp17.6 was present at 2:1 and 4:1, respectively (Figure 2C). Similarly, only no SOD activity in $1 \mathrm{mM} \mathrm{H}_{2} \mathrm{O}_{2}$ was assayed within $20 \mathrm{~min}$, while $20-58 \%$ activity was retained in the presence of Hsp17.6 (Figure 2D).

The addition of four-fold Hsp18.9 also recovered the $\mathrm{HClO}$ - and $\mathrm{H}_{2} \mathrm{O}_{2}$-treated SOD activity, and the $\mathrm{H}_{2} \mathrm{O}_{2}$-treated MDH activity similarly as addition of two-fold Hsp17.6 (Figure 2B-D), and retained higher $\mathrm{HClO}$-treated $\mathrm{MDH}$ activity than addition of fourfold Hsp17.6 (Figure 2A). While, Hsp20.2 exhibited weak effects, so presenting different oxidation protective activities among the three paralogs. The reciprocal addition of fourfold $\mathrm{MDH}$ and SOD did not alleviate the oxidative inactivation of each other from $\mathrm{HClO}$ or $\mathrm{H}_{2} \mathrm{O}_{2}$, thus precluding the possibility that the observed Hsp17.6 oxidation protective activity was from the protein crowding effect. 
A
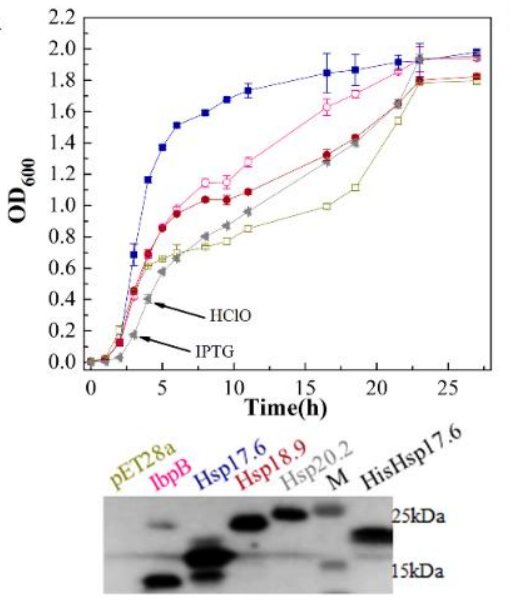

C

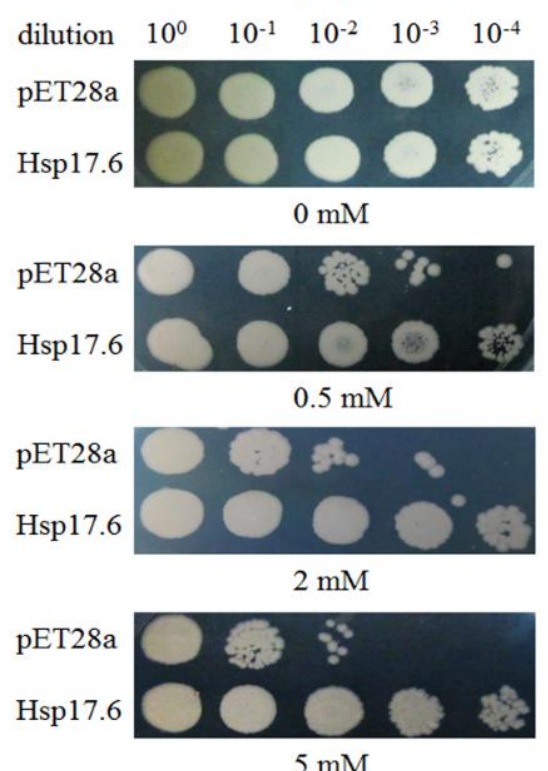

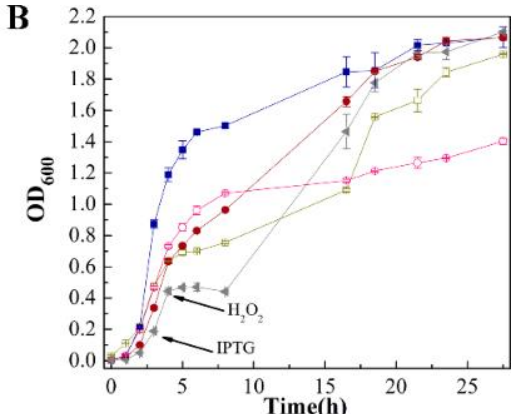

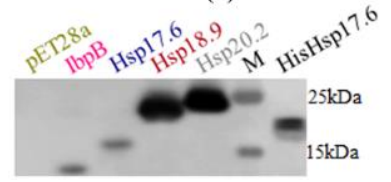

$\mathrm{H}_{2} \mathrm{O}_{2}$
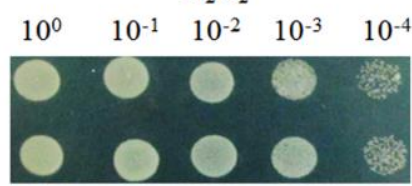

$0 \mathrm{mM}$

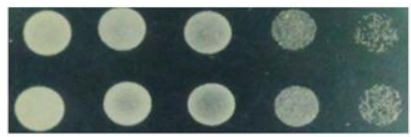

$1 \mathrm{mM}$

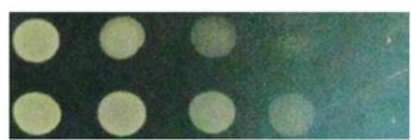

$2 \mathrm{mM}$

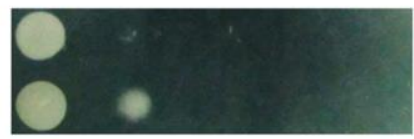

$5 \mathrm{mM}$

Figure 1. The Methanolobus psychrophilus Hsp17.6-expressing Escherichia coli exhibited enhanced growth and survivability in oxidants. The C-terminal His-tag fused Hsp17.6, Hsp18.9, Hsp20.2, and the E. coli IbpA/B were each cloned in the vector pET28a and expressed in E. coli JM109 (DE3), and the vacant vector was expressed as a control. All the strains were cultured in Luria-Bertani (LB) broth containing $50 \mu \mathrm{g} / \mathrm{mL}$ kanamycin at $37^{\circ} \mathrm{C}$, until the mid-exponential phase $0.1 \mathrm{mM}$ IPTG was added to induce sHsps expression at the arrows indicated time. After another hour of incubation, $0.5 \mathrm{mM} \mathrm{HClO}$ (A upper panel) or $2 \mathrm{mM} \mathrm{H}_{2} \mathrm{O}_{2}$ (B upper panel) was added to the cultures. Growth was monitored via measurement of the $\mathrm{OD}_{600}$. $\mathbf{0}$, Hsp17.6; •, Hsp18.9; 4, Hsp20.2; O, IbpAB; and $\square$, empty vector pET28a. The oxidant non-treated growths are shown in Figure S2 D. Experiments were assayed in triplicate, and the averages and standard deviations are shown. Using the His-tag antiserum, western blotting was used to assay the expression of the four proteins (lower panels of $\mathbf{A}$ and $\mathbf{B}$ ) in $20 \mu \mathrm{g}$ of total cell protein three hours after the addition of isopropyl- $\beta$-d-thiogalactoside (IPTG) and $0.2 \mu \mathrm{g}$ purified Hsp17.6 carrying $\mathrm{N}$ terminal His-tag and additional 11 amino acids derived from the vector was included. Western blot signals were visualized by the Tanon-5200 Chemiluminescent Imaging System. (C) Strains carrying Hsp17.6 and the empty vector pET28a were 10 -fold serially diluted and spotted to LB agar plates containing various concentrations of $\mathrm{HClO}$ (left panel) and $\mathrm{H}_{2} \mathrm{O}_{2}$ (right panel). Growths were recorded after overnight incubation at $37^{\circ} \mathrm{C}$. 
A

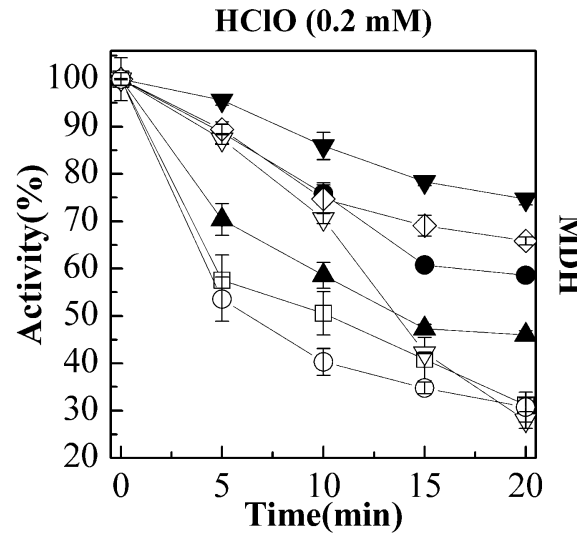

$\mathbf{C}$

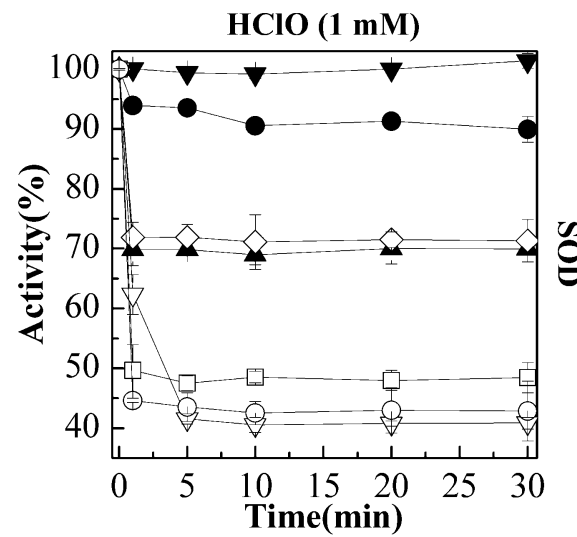

B

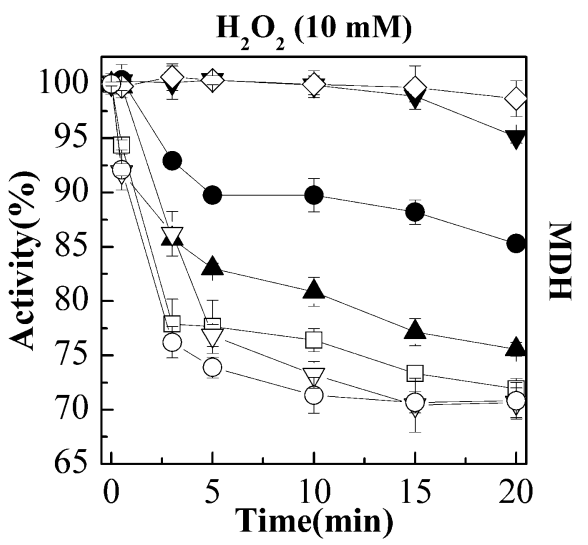

D

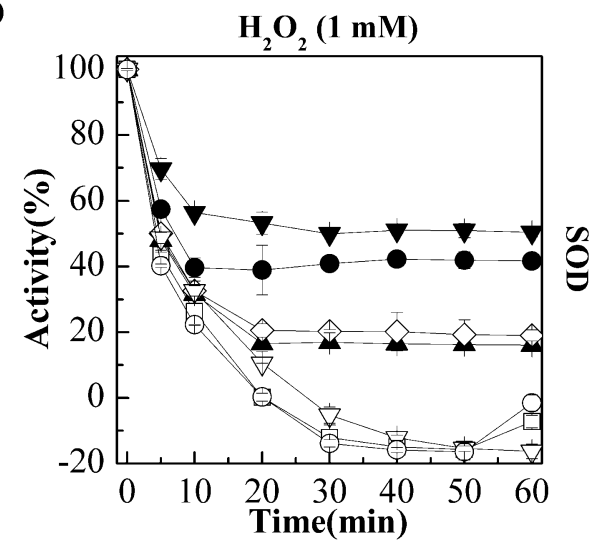

Figure 2. The addition of M. psychrophilus Hsp17.6 alleviated $\mathrm{HClO}$ or $\mathrm{H}_{2} \mathrm{O}_{2}$ oxidized inactivation of malate dehydrogenase $(\mathrm{MDH})$ and superoxide dismutase (SOD). Hsp17.6 was mixed with $5.4 \mu \mathrm{M}$ of $\mathrm{MDH}$ monomer (A,B) or $7.8 \mu \mathrm{M}$ of SOD monomer (C,D) at the indicated molecular ratios, and the two paralogs Hsp18.9 and Hsp20.2 were also mixed with MDH and SOD, respectively. In addition, $\mathrm{MDH}$ and SOD were reciprocally used as a negative control. After addition of the indicated concentrations of $\mathrm{HClO}$ or $\mathrm{H}_{2} \mathrm{O}_{2}$ into the protein mixtures, the corresponding enzyme activities were assayed at different time points. The residual activity percentages were calculated by reference to those at $0 \mathrm{~min}$. The experiments were carried out in triplicate, and the averages and standard deviations are shown. (A). MDH was co-incubated with $0(\square)$, $10.8 \mu \mathrm{M}(\mathbf{\Lambda}), 21.6 \mu \mathrm{M}(\bullet)$, and $43.2 \mu \mathrm{M}(\mathbf{\nabla})$ of Hsp17.6; and $21.6 \mu \mathrm{M}$ of Hsp18.9 $(\diamond)$ or Hsp20.2 $(\nabla)$, or SOD $(\bigcirc)$. $(\mathbf{B})$. MDH was co-incubated with $0(\square), 0.54 \mu \mathrm{M}(\mathbf{\Delta}), 2.7 \mu \mathrm{M}(\bullet)$, and $10.8 \mu \mathrm{M}(\mathbf{\nabla})$ of Hsp17.6; and 21.6 $\mu \mathrm{M}$ of Hsp18.9 $(\diamond)$ or Hsp20.2 $(\nabla)$, or SOD $(\bigcirc)$. (C). SOD was co-incubated with $0(\square), 15.6 \mu \mathrm{M}(\mathbf{\Lambda}), 31.2 \mu \mathrm{M}(\bullet)$, and $62.4 \mu \mathrm{M}(\mathbf{\nabla})$ of Hsp17.6; and $31.2 \mu \mathrm{M}$ of Hsp18.9 $(\diamond)$ or Hsp20.2 $(\nabla)$, or MDH $(\bigcirc)$. (D). SOD was co-incubated with $0(\square), 15.6 \mu \mathrm{M}(\mathbf{\Lambda}), 31.2 \mu \mathrm{M}(\bullet)$, and $62.4 \mu \mathrm{M}$ ( $\mathbf{v})$ Hsp17.6; and $31.2 \mu \mathrm{M}$ of Hsp18.9 $(\diamond)$ or Hsp20.2 ( $\nabla)$, or MDH $(\bigcirc)$.

In addition, $\mathrm{HyPer}$, an $\mathrm{H}_{2} \mathrm{O}_{2}$-specific reporter fluorescence protein, was used as substrate to assay Hsp17.6 in alleviating the oxidative inactivation of proteins. The HyPer protein was constructed by Belousov et al. [26] by inserting the regulatory domain of the E. coli $\mathrm{H}_{2} \mathrm{O}_{2}$-sensing protein OxyR into the fluorescent protein cpYFP. When $\mathrm{H}_{2} \mathrm{O}_{2}$ oxidizes Cys199 and Cys208 to form a disulfide bond, HyPer emits green fluorescence. With the addition of $1 \mathrm{mM} \mathrm{H}_{2} \mathrm{O}_{2}$ to $450 \mathrm{nM}$ HyPer, elevated fluorescence was detected; and the addition of $1.8 \mu \mathrm{M}$ Hsp17.6 or Hsp18.9 to the mixture reduced the $\mathrm{H}_{2} \mathrm{O}_{2}$-induced HyPer fluorescence increasing (Figure S3). Whereas, no such effect was assayed for Hsp20.2. This provides further evidence that Hsp17.6 and Hsp18.9, but not Hsp20.2, are capable of alleviating the oxidation inactivation of proteins.

2.4. Hsp17.6 Appeared to Alleviate the $\mathrm{H}_{2} \mathrm{O}_{2}$-Oxidized Disulfide Linking and the HClO-Induced Degradation of Proteins

To probe the mechanisms of Hsp17.6 in alleviation of the oxidative inactivation of proteins, we, using non-reducing sodium dodecyl sulfate polyacrylamide gel electrophore- 
sis (SDS-PAGE), analyzed the oxidative status of oxidant-treated MDH and SOD in the presence or absence of Hsp17.6. As shown in Figure 3, a 30 min-treatment with $1 \mathrm{mM}$ $\mathrm{H}_{2} \mathrm{O}_{2}$ caused certain proportions of MDH and SOD to migrate slower with increased apparent molecular weights (lanes 4 of Figure $3 \mathrm{~A}, \mathrm{~B}$ ); however, the larger protein bands disappeared with addition of $2 \mathrm{mM}$ DTT (lanes 2 of Figure 3A,B). This indicates that $\mathrm{H}_{2} \mathrm{O}_{2}$ oxidation caused disulfide-linked oligomerization of $\mathrm{MDH}$ or dimerization of SOD based on the theoretical molecule weights of the MDH monomer (32 kDa) and SOD monomer (21 kDa). With the addition of Hsp17.6 at molar ratios of 2-8:1, the oxidized MDH oligomer (Figure 3A, lanes 2-8), and the SOD dimer contents (Figure 3B, lanes 5-7) decreased, and the monomers increased from about $70 \%$ to $95 \%$.
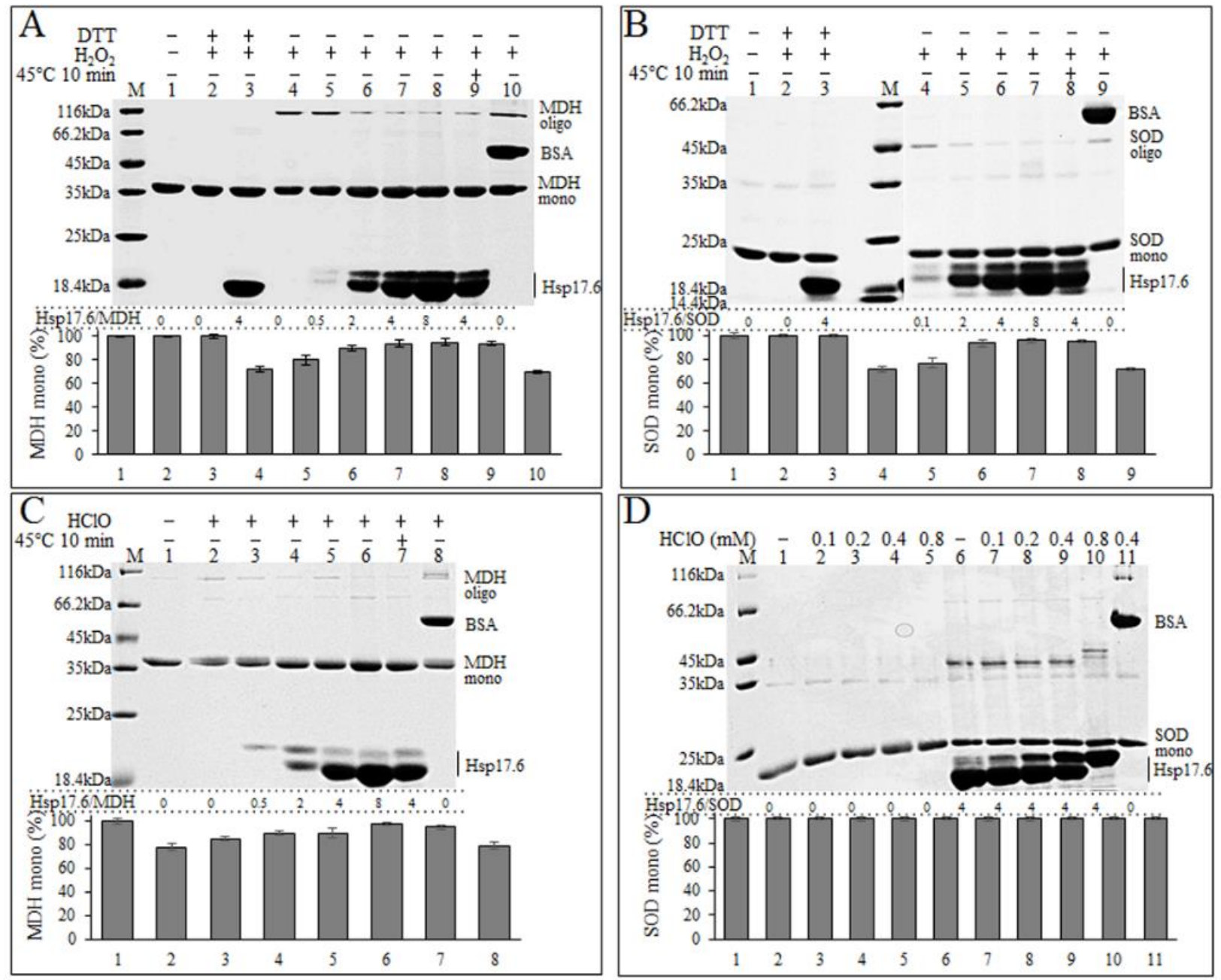

Figure 3. The presence of Hsp17.6 reduced the oxidant-induced disulfide linking protein contents. Protein mixtures of $\mathrm{MDH}(\mathbf{A})$ or SOD (B) with various molecular ratios of Hsp17.6 were preheated at $45^{\circ} \mathrm{C}$ for 10 min before $1 \mathrm{mM} \mathrm{H}_{2} \mathrm{O}_{2}$ treatment for $30 \mathrm{~min}$, and then reduced with $2 \mathrm{mM}$ DTT for $30 \mathrm{~min}$. Mixtures of $\mathrm{MDH}$ with various ratios of Hsp17.6 were also treated for $30 \mathrm{~min}$ with $0.4 \mathrm{mM} \mathrm{HClO}(\mathbf{C})$, and SOD with four-fold Hsp17.6 was treated for $30 \mathrm{~min}$ with $0-0.8 \mathrm{mM} \mathrm{HClO}$ (D). All the treatments were performed at $37^{\circ} \mathrm{C}$ unless otherwise indicated. The treated protein mixtures were analyzed on non-reducing sodium dodecyl sulfate polyacrylamide gel electrophoresis (SDS-PAGE) (12\%) and stained by Coomassie blue. Beneath the gels shows the molecular ratios of Hsp17.6 to the substrate proteins and the percentages of the substrate monomer band intensities referenced to the non-treated ones. The bovine serum albumin (BSA) at 0.5:1 molecular ratio to $\mathrm{MDH}$ or SOD was included as a control. Protein markers and the tested proteins are shown at the left and right of the gels, respectively. The MDH and SOD monomer intensities were scanned and calculated using ImageJ, and the averages and standard deviations from triplicate experiments are shown. 
Preheat treatment at $45{ }^{\circ} \mathrm{C}$ did not change the effect of Hsp17.6 in reducing the oxidized oligomer contents, and the tested bovine serum albumin (BSA) did not show protection on MDH (Figure 3A, lane 10) and SOD oxidation (Figure 3B, lane 9). It is worthy of noting that a relatively larger protein band of Hsp17.6 occurred in the $\mathrm{H}_{2} \mathrm{O}_{2}$-treated mixtures (Figure 3). This assumes that Hsp17.6 could protect the substrate proteins from oxidant-caused disulfide-bond formation by itself being oxidized.

Unlike $\mathrm{H}_{2} \mathrm{O}_{2}$ oxidation, which led to disulfide linkages in proteins, $0.4 \mathrm{mM} \mathrm{HClO}$ caused oxidative degradation of $\mathrm{MDH}$ (Figure 3C, lane 2), and a severe degradation occurred in $0.8 \mathrm{mM} \mathrm{HClO}$ (Figure $\mathrm{S} 4$ ). HClO-caused $\mathrm{MDH}$ degradation was gradually mitigated by the addition of 0.5-8:1 Hsp17.6 (Figure 3C, lane 3-6). In contrast, $\mathrm{HClO}$ appeared to cause neither the protein size changes nor the degradation of SOD; rather, the addition of Hsp17.6 induced a slower migrating protein band presumably of SOD (Figure 3D).

It is worth noting that in the presence of higher oxidant concentrations, like $0.8 \mathrm{mM}$ $\mathrm{HClO}$, Hsp17.6 was fully oxidized, however the MDH oligomer contents were not further reduced (Figure S4). This indicates the limitation of Hsp17.6 as an antioxidant. Considering that $\mathrm{HClO}$ treatment markedly reduced the SOD activity (Figure 2C), $\mathrm{HClO}$ oxidation resultant disulfide linkages of proteins could be among the multiple oxidative consequences, such as the irreversible oxidation to sulfonic acid or sulfenic acid of the thiol groups and protein carbonylation.

\subsection{Mass Spectrometry Detected the Oxidized Amino Acid Residues of Hsp17.6}

Unlike thioredoxin or other redox proteins that reduce $\mathrm{H}_{2} \mathrm{O}_{2}-$ or $\mathrm{HClO}-$ oxidized proteins via oxidation of the thiol groups of cysteine, the Hsp17.6 protein does not contain cysteine residues. To obtain insights into the molecular changes of Hsp17.6 in alleviating the oxidation of other proteins, it was treated by $0-5 \mathrm{mM} \mathrm{H}_{2} \mathrm{O}_{2}$ and $0-0.8 \mathrm{mM} \mathrm{HClO}$. Compared with the non-treated one, the $\mathrm{H}_{2} \mathrm{O}_{2}$ - and $\mathrm{HClO}$-treated Hsp17.6 proteins were run as two bands on non-reducing SDS-PAGE (Figure 4A,B inserts) similar as the oxidanttreated protein mixtures with $\mathrm{MDH}$ and SOD.

Next, $5 \mathrm{mM} \mathrm{H}_{2} \mathrm{O}_{2}$ - and $0.4 \mathrm{mM} \mathrm{HClO}$-treated Hsp17.6 proteins were subjected to high performance liquid chromatography-mass spectrometry (LC-MS) to determine the molecular weights. Compared with the non-treated Hsp17.6 (Figure 4C), the $\mathrm{H}_{2} \mathrm{O}_{2}$-treated proteins increased by about 16, 32, and 48 daltons (Figure 4A), and the HClO-treated proteins increased by about $32,48,64,80$, and 96 daltons (Figure 4B). This indicates that oxygen atoms may be introduced into Hsp17.6 upon oxidant treatment.

The oxidization enlarged Hsp17.6 protein was tryptase hydrolyzed and subjected to liquid chromatography-tandem mass spectrometry (LC-MS/MS) identification of the oxidized residues. The non-oxidized smaller band was analyzed in parallel. Compared with the relative abundances of the oxidized peptide fragments in $\mathrm{H}_{2} \mathrm{O}_{2}$ - and $\mathrm{HClO}$-treated vs. non-treated Hsp17.6, LC-MS/MS identified methionine (M), aspartate (D), asparagine (N), and lysine (K) as the main residues with oxygen atoms introduced (Figure S5). As shown in Table S1, in $\mathrm{H}_{2} \mathrm{O}_{2}$-treated Hsp17.6, 74\% M16, 100\% M25, and 69\% M103 were introduced with an extra oxygen atom compared with $32 \%, 47 \%$, and $48 \%$ oxygen introduction in the non-treated protein. Similarly, 1.5-5-fold higher oxygen introduction was found in D44, D46, D53, D66, and D132 in the $\mathrm{H}_{2} \mathrm{O}_{2}$-treated vs. non-treated Hsp17.6. Collectively, mass spectrometry identified that, except for methionine residues, the aspartate and asparagine residues of $\mathrm{Hsp} 17.6$ were readily oxidized by $\mathrm{H}_{2} \mathrm{O}_{2}$ and $\mathrm{HClO}$. This indicates that $\mathrm{Hsp} 17.6$ might exert a protective role in protein oxidation via consumption of the oxidants that the protein encounters.

In addition, LC-MS/MS also identified similar extra oxygen atoms in HClO-oxidized MDH protein (Table S1), which was sliced from the non-reducing SDS-PAGE (Figure 3C, lane 2); while reduced abundances of oxygen introduction in $\mathrm{MDH}$ were found in the presence of Hsp17.6 (Table S1; Figure 3C, lane 5). This result confirmed the protective activity of Hsp17.6. 


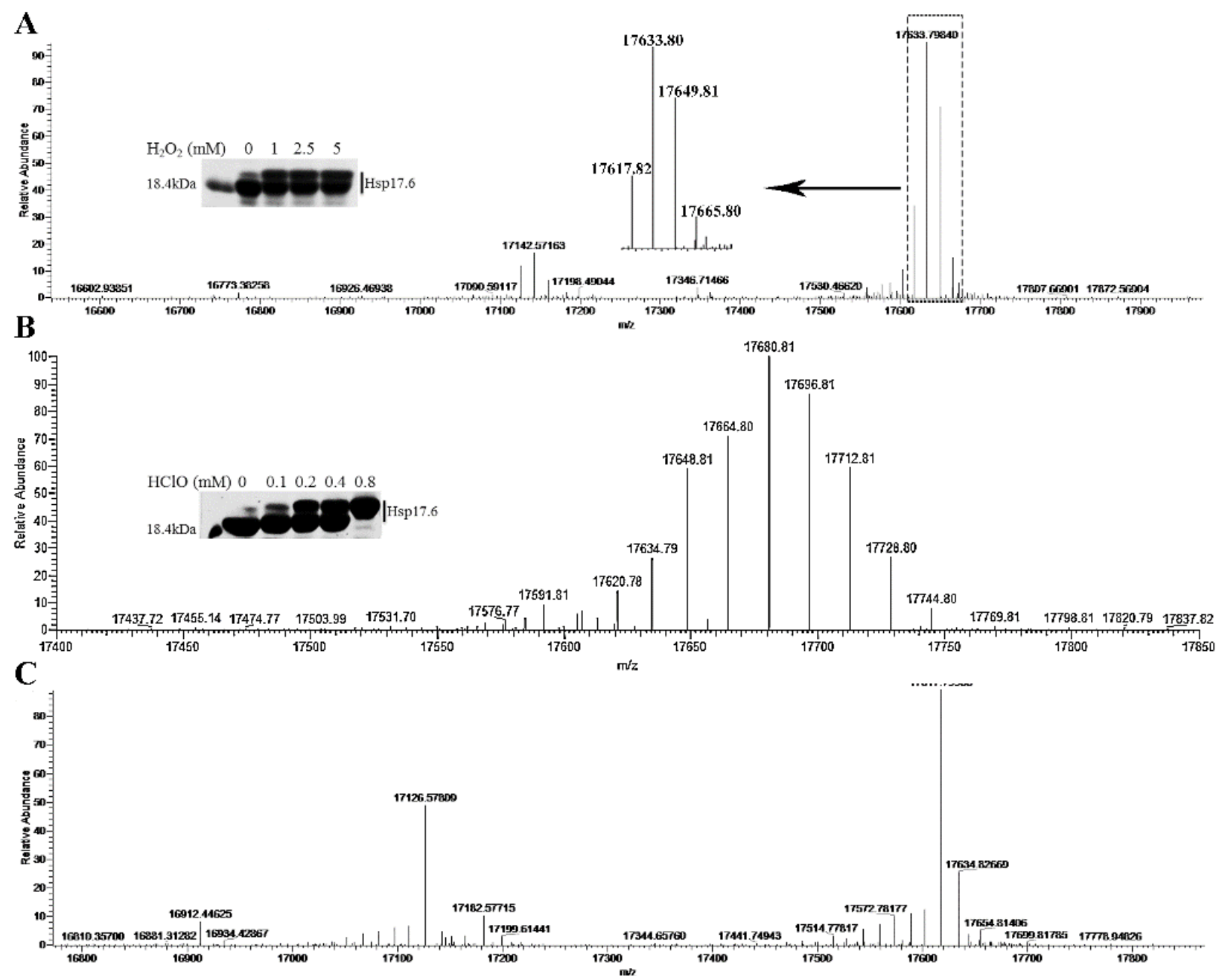

Figure 4. Identification of the molecular weights of $\mathrm{Hsp} 17.6$ after treatment with $\mathrm{H}_{2} \mathrm{O}_{2}$ or $\mathrm{HClO}$ using high performance liquid chromatography-mass spectrometry (LC-MS). Hsp17.6 protein treated with $5 \mathrm{mM} \mathrm{H}_{2} \mathrm{O}_{2}$ (A) or $0.4 \mathrm{mM} \mathrm{HClO}$ (B) or without treatment (C) subjected to orbitrap fusion for analysis. Hsp17.6 protein treated for 30 min with $0-5 \mathrm{mM}^{\circ} \mathrm{H}_{2} \mathrm{O}_{2}(\mathbf{A}$, insert) or 0-0.8 mM of $\mathrm{HClO}$ (B, insert) and separated on non-reducing SDS-PAGE.

\subsection{Substitution of Aspartate Residues Reduced the Protection of Hsp17.6 on Protein Oxidative Inactivation \\ Given that the Hsp17.6 asparagine residues were less sensitive to $\mathrm{H}_{2} \mathrm{O}_{2}$ and $\mathrm{HClO}$ oxidization than aspartate (Table S1), we constructed an asparagine substitution on D44, D46, D53, D66, and D132 and a double mutation of D44 and D46. The six Hsp17.6 protein mutants were each overexpressed in E. coli. Except for $\mathrm{D} 44 \mathrm{~N}$, the remaining five were purified as soluble proteins, and were assayed for alleviating $\mathrm{MDH}$ oxidation by $\mathrm{H}_{2} \mathrm{O}_{2}$ and $\mathrm{HClO}$. We determined that compared to almost $100 \% \mathrm{MDH}$ activities assayed in the presence of wild-type Hsp17.6, 85-95\% activities in $10 \mathrm{mM} \mathrm{H}_{2} \mathrm{O}_{2}$ (Figure 5A) and 54-91\% activities in $0.4 \mathrm{mM} \mathrm{HClO}$ (Figure $5 \mathrm{~B}$ ) were found when the five mutants were added. Mutants of D132N and D44N/D46N caused a significant loss to the protective activity.}


A
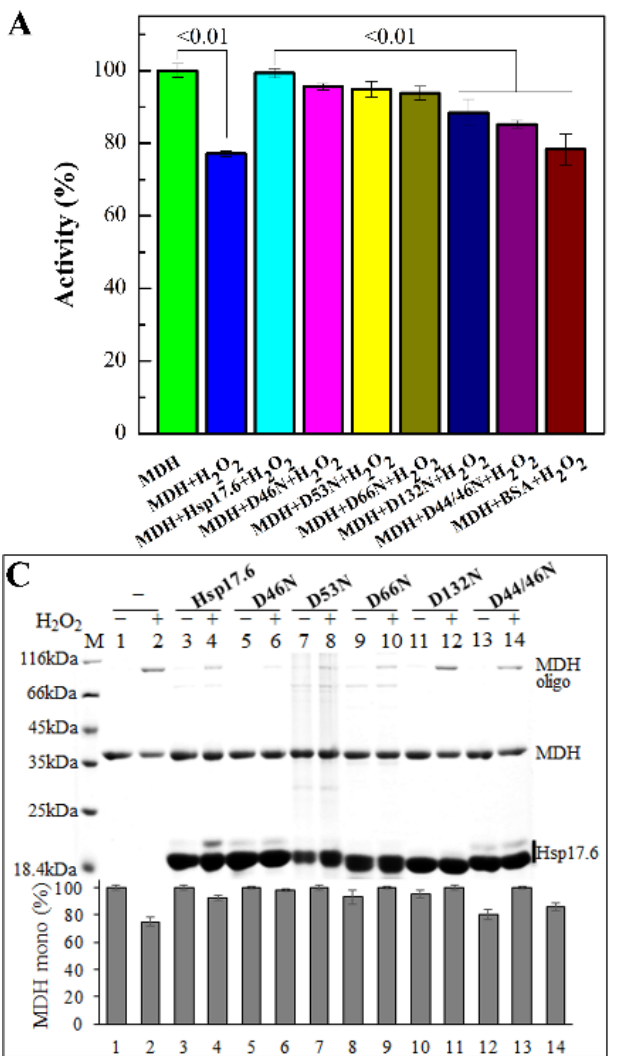

B
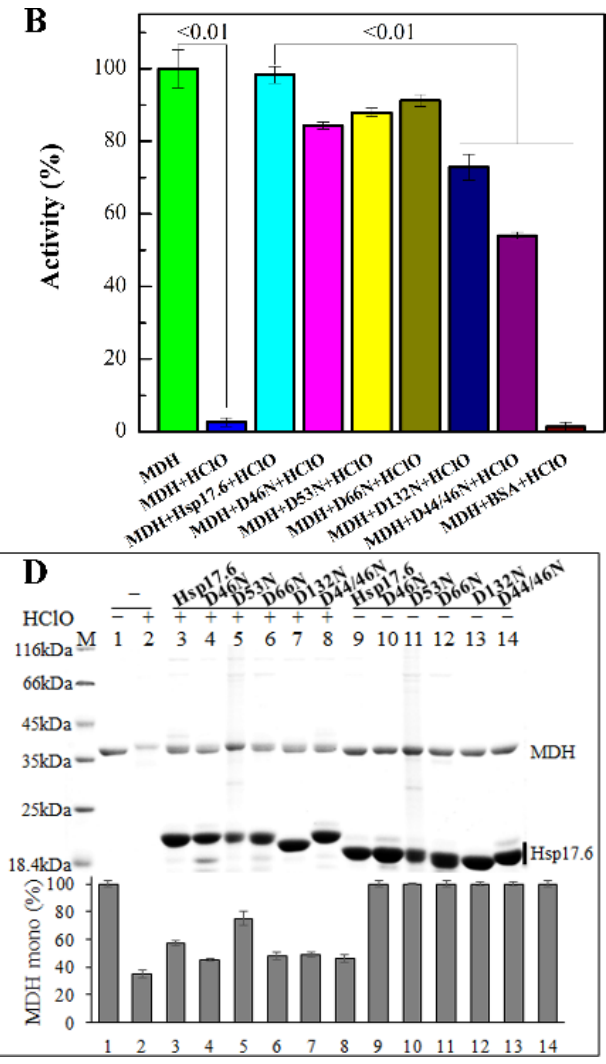

Figure 5. Substitution of certain aspartate residues reduced the Hsp17.6 effect in alleviating the oxidative inactivation of MDH. MDH was mixed with each of the wild-type and the aspartate mutants of Hsp17.6 at 2:1 (A) or 4:1 (B), and the activities in $10 \mathrm{mM} \mathrm{H}_{2} \mathrm{O}_{2}(\mathbf{A})$, or $0.4 \mathrm{mM} \mathrm{HClO}(\mathbf{B})$ were assayed using the same approach as in Figure 2. The averages and standard deviations of triplicate experiments are shown. Difference significances (indicated at the diagram top) of the oxidant-treated MDH enzymatic activities in the presence of Hsp17.6 wild-type and residue mutants were statistically analyzed by the ANOVA and Tukey multiple comparison test. Non-reducing SDS-PAGE was used to analyze the oxidation states of $\mathrm{H}_{2} \mathrm{O}_{2}-(\mathbf{C})$ and $\mathrm{HClO}-(\mathbf{D})$ treated $\mathrm{MDH}$, and $\mathrm{Hsp} 17.6$ and its mutants. Oxidant treatments were performed at $37^{\circ} \mathrm{C}$ for $60 \mathrm{~min}$. The Non-reducing SDS-PAGE was Coomassie blue stained. Protein markers and the tested proteins are shown at the left and right of the gels, respectively. MDH monomer band intensities were scanned and calculated using ImageJ, and the averages of and the standard deviations from triplicate experiments are shown.

Assaying these protein mixtures on non-reducing SDS-PAGE, we found that compared with the wild-type Hsp17.6 addition, relatively higher contents of $\mathrm{H}_{2} \mathrm{O}_{2}$-induced $\mathrm{MDH}$ oligomers were observed when added with the mutants of D132N and D44N/D46N (Figure 5C); meanwhile, the larger band in the five $\mathrm{H}_{2} \mathrm{O}_{2}$-treated mutants almost disappeared. This result suggests that the mutated residues could be the oxidized targets of Hsp17.6.

Compared with the wild-type Hsp17.6 in mitigating HClO-induced MDH degradation, the mutants D46N, D66N, D132N, and D44N/D46N only exhibited weak effects. These residues appeared being more oxidized in the presence of $\mathrm{HClO}$ as indicated by mass spectrometry analysis, suggesting that they could be the oxidation targets of Hsp17.6; however, the oxidized larger band of Hsp17.6 only disappeared in D132N (Figure 5D). These data suggest that mutated aspartate residues, like D132, could be the general oxidized targets of Hsp17.6 by the two oxidants and, together with the other aspartate residues, contribute to the antioxidative role of Hsp17.6. 


\subsection{The Hsp17.6 Aspartate Residue Mutants Reduced Attenuating Oxidant-Suppressed E. coli Growth}

To further verify the role of the mutated aspartate residues in the Hsp17.6 oxidation protection, the five mutants were introduced into E. coli JM109 (DE3) via the vector pET28a, and the wild-type Hsp17.6 and empty pET28a expressing strains were included as controls. Growths of $0.5 \mathrm{mM} \mathrm{HClO}$ - or $2 \mathrm{mM} \mathrm{H}_{2} \mathrm{O}_{2}$-treated strains were followed. Expect for D46N and D53N, which were poorly expressed in the $\mathrm{H}_{2} \mathrm{O}_{2}$ - and $\mathrm{HClO}$-treated cultures, respectively, most of the Hsp17.6 mutant proteins were expressed (Figure 6 lower panels).
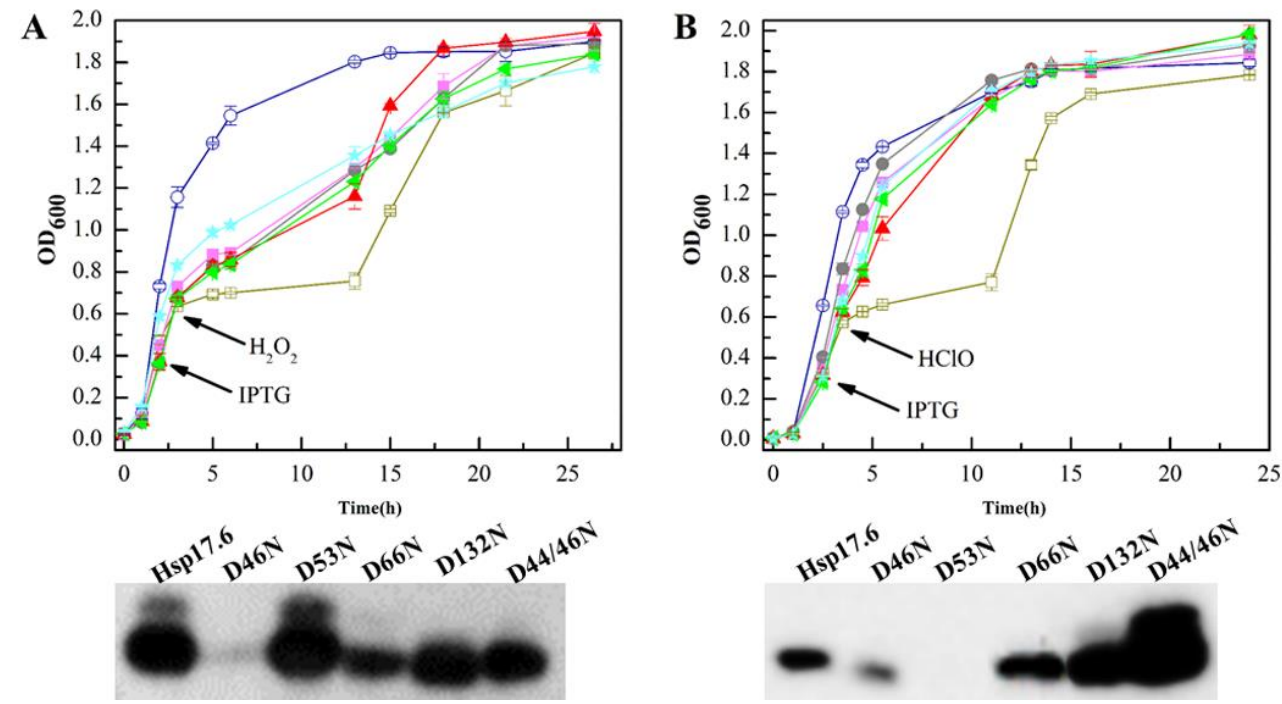

Figure 6. The Hsp17.6 aspartate mutants reduced the effect of attenuating oxidant-suppressed growth of E. coli. Five aspartate substitution mutants, D46N $(\square), \mathrm{D} 66 \mathrm{~N}(\bullet), \mathrm{D} 53 \mathrm{~N}(\triangleleft), \mathrm{D} 132 \mathrm{~N}(\star)$, and D44N/46N $(\Delta)$, were each introduced into E. coli JM109(DE3) via the vector pET28a. The wild-type Hsp17.6 (○) and empty pET28a ( $\square$ ) were expressed as controls. The E. coli strains were grown in LB broth, and, after 2-2.5 h-incubation, when the $\mathrm{OD}_{600}$ reached 0.6-0.8, 0.1 mM IPTG was added to induce the expression of the Hsp17.6 mutants. After $1 \mathrm{~h}$ of induction, $2 \mathrm{mM} \mathrm{H}_{2} \mathrm{O}_{2}$ (A upper panel) or $0.5 \mathrm{mM}$ $\mathrm{HClO}$ (B upper panel) were added. Growth was monitored by measurement of the $\mathrm{OD}_{600}$. The protein expression was assayed $3 \mathrm{~h}$ after the addition of IPTG by western blot using the His-tag antiserum (lower panels of A and B) and visualized by the Tanon- 5200 Chemiluminescent Imaging System. Triplicate cultures of each mutant were assayed, and the averages and standard deviations are shown.

However, compared with the wild-type Hsp17.6-expressing E. coli, those carrying the mutants all exhibited marked reduced growth when treated with $\mathrm{H}_{2} \mathrm{O}_{2}$ (Figure 6A upper panel), and the growths were recovered until the stationary phase presumably due to the E. coli catalase removing the added $\mathrm{H}_{2} \mathrm{O}_{2}$. The mutant-expressing E. coli did not exhibit increased sensitivity to $\mathrm{HClO}$ (Figure $6 \mathrm{~B}$ upper panel). These results confirm that the mutated aspartate residues have contributions to Hsp17.6 in alleviating the $\mathrm{H}_{2} \mathrm{O}_{2-}$, but not $\mathrm{HClO}-$ oxidized inactivation of proteins and in elevating the bacterial growth under oxidative stress.

\section{Discussion}

Small heat shock proteins are well known in mitigation of protein aggregation at high temperatures. This work reports that the archaeal sHsp Hsp17.6 and the paralog Hsp18.9 from M. psychrophilus, a psychrophilic methanogenic archaeon, alleviated the protein oxidative inactivation and oxidative stress of E. coli imposed by $\mathrm{H}_{2} \mathrm{O}_{2}$ and $\mathrm{HClO}$, thus, exhibiting an oxidation protection function.

Some of the Hsp17.6 aspartate residues appeared susceptive to oxidants, and their oxidations could consume certain oxidants and reduce the oxidant insult to proteins SOD and $\mathrm{MDH}$, and reduce oxidized disulfide-linked oligomers of them. Hsp17.6 orthologs 
are distributed among some archaea and bacteria, and the predicted oxidant-susceptive aspartate residues are conserved in the orthologs (Figure S6); therefore, the reported oxidation protective role of the archaeal sHsps in this work could be widely applicable.

Higher dissolved oxygen contents could occur in cold water systems [27]; therefore, the inhabiting psychrophilic or psychrotolerant organisms would likely have evolved more approaches to cope with the increased oxidative stress compared with mesophiles. Previously, we found that M. psychrophilus R15 was able to survive up to $0.8 \mathrm{mM}$ paraquat, a redox-cycling drug, and in comparison, a mesophilic methanogen only tolerated as low as $0.05 \mathrm{mM}$ paraquat [21].

In addition to oxidant-removing systems, like the anaerobe-specific superoxide reductase (SOR) and aerobe-typical superoxide dismutase-catalase, the sHsps with oxidation protective roles could also contribute to the higher survivability of M. psychrophilus in reactive oxygen species (ROS). The three $M$. psychrophilus sHsps all fell in the top 10 overrepresentative expressed gene categories in lower temperatures [22], implying that they could play roles in assisting the archaeon to survive in either cold or higher oxidative stress in cold. Nevertheless, the physiological functions of Hsp17.6 in M. psychrophilus remain to be elucidated until a genetic manipulation system is developed in the archaeon.

Bacterial sHsps were also reported in protection of bacteria from oxidative stress. The E. coli IbpA/B proteins were determined to protect the bacterium against copper-ioninduced oxidative stress, and in the presence of $\mathrm{IbpA} / \mathrm{B}$ lower levels of the carbonylated proteins were found in copper-ion-treated E. coli [14]. Sakthivel et al. [15] also reported that HspA endowed Synechococcus with higher survivability in $\mathrm{H}_{2} \mathrm{O}_{2}$, through specifically suppressing $\mathrm{H}_{2} \mathrm{O}_{2}$ bleaching phycocyanin via a direct interaction with phycobilisome. However, the molecular details regarding how the two bacterial sHsps protect protein oxidation either from copper-induced ROS or directly from $\mathrm{H}_{2} \mathrm{O}_{2}$ remain to be determined.

The archaeal Hsp17.6 could be sensitive to oxidants, and an oxidized larger band occurred even during protein preparation (Figure 4A). Though the mechanism details have not been elucidated yet, this work determined that the archaeal Hsp17.6 protected the oxidative inactivation of proteins most likely through aspartate residue oxidation to consume the oxidants $\mathrm{H}_{2} \mathrm{O}_{2}$ and $\mathrm{HClO}$. Conventionally, it is believed that cysteine and methionine are the two residues most vulnerable to $\mathrm{H}_{2} \mathrm{O}_{2}$ oxidation, and $\mathrm{H}_{2} \mathrm{O}_{2}$ did induce disulfide-linked MDH and SOD oligomers as observed in this study (Figure 3A,B).

Low concentrations of $\mathrm{HClO}$ could rapidly induce the oxidized protein unfolding in vitro and cause irreversible protein aggregation in vivo [28]. The bacterial chaperone Hsp33 is activated when its cysteine is oxidized by oxidants, such as $\mathrm{H}_{2} \mathrm{O}_{2}$ or $\mathrm{HClO}$, and inhibits the aggregation of other proteins [28]. Meanwhile, oxidation of the Hsp33 $\mathrm{Zn}^{2+}$ coordinated cysteine residues alter the protein conformation due to the $\mathrm{Zn}^{2+}$ lost [29]. The Hsp17.6 aspartate residues appear to be readily oxidized by introduction of oxygen atoms into the protein; however, the oxygen modified aspartate groups remain to be identified.

Through amino acid sequence comparison among the Hsp17.6 orthologs from archaeal and bacterial species, we found that certain mutated aspartate residues in this study, in particular D53, D66, and D132, were conserved (Figure S6), while some of them were absent in Hsp20.2 (Figure S1), the paralog did not show the same oxidation protective activity (Figures 1 and 2). These results suggest that the aspartate residues could play a key role in the oxidative protection of the sHsps.

\section{Materials and Methods}

\subsection{Materials}

The citrate synthase and mitochondrial malate dehydrogenase from porcine heart, and bovine serum albumin and the superoxide dismutase from Escherichia coli cell lyophilized powder were all purchased from Sigma-Aldrich company (St. Louis, MO, USA). Luciferase was purchased from Promega company (Madison, WI, USA). Sodium hypochlorite and hydrogen peroxide were purchased from Macklin (Shanghai, China). Gibson Assembly ${ }^{\circledR}$ Master Mix was purchased from NEB (Ipswich, MA, USA). The ubiquitin-like-protease 
1 that is the C-terminal fragment (403-621 amino acids) of the yeast small ubiquitin-like modifier protease (SUMO protease ULP1, Gene ID: 856087) was fused with a His6-tag at the N-terminal, and heterogenous expressed in E. coli and purified.

\subsection{Growth Experiments}

The archaeal Hsp17.6, Hsp18.9 and Hsp20.2, and the E. coli IbpA/B were each cloned into the plasmid pET28a and transformed into E. coli JM109(DE3). A single colony of each transformant was cultured in Luria-Bertani (LB) broth at $37{ }^{\circ} \mathrm{C}$ overnight. After adjusting cell numbers, $1 \%(v / v)$ culture was inoculated into $50 \mathrm{~mL}$ LB medium containing $50 \mu \mathrm{g} / \mathrm{mL}$ kanamycin that was contained in $100 \mathrm{~mL}$-Erlenmeyer flask and incubated at $37^{\circ} \mathrm{C}$ with shaking at $200 \mathrm{rpm}$. Until 2-3 h-incubation when $\mathrm{OD}_{600}$ reached $0.4-0.6$, $0.1 \mathrm{mM}$ isopropyl- $\beta$-d-thiogalactoside (IPTG) was added to induce protein expression of the Hsps. After another hour induction, triplicate cultures were respectively incubated at $22{ }^{\circ} \mathrm{C}, 37^{\circ} \mathrm{C}$ and $45^{\circ} \mathrm{C}$, and the other replicate cultures were added with $2 \mathrm{mM} \mathrm{H}_{2} \mathrm{O}_{2}$ or $0.5 \mathrm{mM} \mathrm{HClO}$ for oxidant-treated growth assay. $\mathrm{OD}_{600}$ was measured in an interval of one or two hours during the growth.

For oxidant survival experiments, E. coli strains that are expressed with Hsp17.6 or empty vector were cultured as above. After $2.5 \mathrm{~h}$-IPTG induction, cultures are adjusted to the same $\mathrm{OD}_{600}$ values of 1.0 and each $6 \mu \mathrm{L}$ of 10 -fold diluted cultures were spotted on $1.5 \% \mathrm{LB}$ agar plates that contain $50 \mu \mathrm{g} / \mathrm{mL}$ kanamycin, $0.1 \mathrm{mM}$ IPTG and $0-5 \mathrm{mM}$ of $\mathrm{H}_{2} \mathrm{O}_{2}$ or $\mathrm{HClO}$ as indicated. After overnight incubation at $37^{\circ} \mathrm{C}$, growths were recorded.

\subsection{Construction of Hsp17.6 Residue Substitution Mutants}

The genomic DNA of Methanolobus psychrophilus R15 was extracted using Bacteria Genome DNA extraction kit (OMEGA, New York, USA) and used as PCR template. Primers were designed according to the genome sequence [21] and synthesized by Sangon Company (Shanghai, China). The Hsp17.6 gene (Mpy_2176) was amplified using the primer pair listed in Table S2, and cloned into pET28a. The residue substitution mutants were constructed through PCR amplification of pET28a-hisSUMO-Hsp17.6 or pET28a-Hsp17.6his using primers containing mutated triple-base with site-directed gene mutagenesis kit (Beyotime Biotechnology Company, Shanghai, China). The constructs were transformed into E. coli DH5 $\alpha$, and correct transformants were selected on LB plates containing $50 \mu \mathrm{g} / \mathrm{mL}$ kanamycin and verified by PCR and sequencing.

\subsection{Protein Expression and Purification}

The archaeal Hsp17.6, Hsp18.9 and Hsp20.2 genes were each fused a $6 \times$ His plus SUMO (small ubiquitin-like modifier) tag at the N-terminals the N-terminal via Gibson assembly. The constructs were each cloned into pET28a, and after DNA sequencing examination, correct plasmids were transformed into E. coli BL21(DE3). A single E. coli colony was inoculated into LB broth with $50 \mu \mathrm{g} / \mathrm{mL}$ kanamycin and $200 \mathrm{rpm}$-shaking cultured at $37^{\circ} \mathrm{C}$. When $\mathrm{OD}_{600}$ reached 0.4 , one $\mathrm{mM} \mathrm{IPTG}$ was added to induce expression of the sHsps, and after another $6 \mathrm{~h}$-incubation, cells were harvested and resuspended in binding buffer (20 mM sodium phosphate, $\mathrm{pH} 8.0,500 \mathrm{mM} \mathrm{NaCl}, 20 \mathrm{mM}$ imidazole). Cells were lysed by ultrasonication using JY92-2D ultrasonic cell crusher (Xinzhi Biotechnology Co. LTD, Ningbo, China) at $400 \mathrm{~W}$ for $30 \mathrm{~min}$, and cell lysates were eluted through His Trap HP (GE Healthcare) to capture sHsps. The purified proteins were then removed the SUMO tag with His-tagged SUMO protease ubiquitin-like protease 1 via dialysis against the binding buffer, and then loaded to the His Trap HP again. The eluate was collected and further purified via superdex200 size exclusion chromatography for $30 \mathrm{~mL}$ elution of $0.5 \mathrm{~mL} / \mathrm{min}$ in a buffer containing $20 \mathrm{mM}$ Tris, $150 \mathrm{mM} \mathrm{NaCl}$ and $5 \%$ glycerol. The sHsp preparations were concentrated and stored at $-80^{\circ} \mathrm{C}$. 


\subsection{Enzymatic Assays on Oxidants Treated Proteins}

A final concentration of $5.4 \mu \mathrm{M} \mathrm{MDH}$ was mixed with each $0-43.2 \mu \mathrm{M}$ of Hsp17.6, and 21.6 $\mu \mathrm{M}$ of Hsp18.9 or Hsp20.2, or SOD in 0.1 M potassium phosphate buffer (pH7.5). After treated with $0-10 \mathrm{mM} \mathrm{H}_{2} \mathrm{O}_{2}$ or $0-0.4 \mathrm{mM} \mathrm{HClO}$ for a given time periods, $\mathrm{MDH}$ activity was assayed using oxaloacetate reduction method [30]. Briefly, $5 \mu \mathrm{L}$ of the oxidant treated protein mixture were added to a final volume of $1 \mathrm{~mL}$ potassium phosphate buffer containing $0.2 \mathrm{mM} \mathrm{NADH}$ and $5 \mathrm{mM}$ oxaloacetate. Absorbance of $340 \mathrm{~nm}$ was monitored by a spectrophotometer (UV-2550, SHIMADZU, Kyoto, Japan) at $25^{\circ} \mathrm{C}$ at 30 s-interval for $2 \mathrm{~min}$. Measurements were done for triplicate samples.

A final concentration of $7.8 \mu \mathrm{M}$ SOD was mixed with $0-62.4 \mu \mathrm{M}$ Hsp17.6, and $31.2 \mu \mathrm{M}$ of Hsp18.9 or Hsp20.2, or MDH in a Tris-EDTA buffer (50 mM Tris, $100 \mathrm{mM}$ EDTA, pH8.0). After treated with $0-1 \mathrm{mM} \mathrm{H}_{2} \mathrm{O}_{2}$ or $0-1 \mathrm{mM} \mathrm{HClO}$ for a given time period, SOD activity was measured by the pyrogallol (1,2,3-trihydroxybenzene) autoxidation method [31]. Briefly, $120 \mu \mathrm{L}$ of the oxidant treated protein mixture were added to a final volume of $600 \mu \mathrm{L}$ Tris-EDTA buffer containing $10 \mathrm{mM}$ pyrogallol. Absorbance at $325 \mathrm{~nm}$ was monitored by a UV-2550 spectrophotometer at $25^{\circ} \mathrm{C}$ at an interval of $30 \mathrm{~s}$ for $5 \mathrm{~min}$. Triplicate samples were assayed.

\subsection{Light Scattering Assay}

Light scattering assay was used to assess the roles of sHsps in reducing protein thermal aggregation. Citrate synthase (CS) and luciferase were used as the substrate proteins. CS monomer in $600 \mathrm{nM}$ was incubated with $0-12 \mu \mathrm{M}$ of Hsp17.6, Hsp18.9 and Hsp20.2 in $40 \mathrm{mM}$ HEPES-KOH, pH7.5. While, $1 \mu \mathrm{M}$ of luciferase was incubated with $0-20 \mu \mathrm{M}$ of each of sHsps in $20 \mathrm{mM}$ tris, $150 \mathrm{mM} \mathrm{NaCl}, \mathrm{pH}$ 8.0. The protein mixtures were incubated at $45^{\circ} \mathrm{C}$ and the light scattering at $360 \mathrm{~nm}$ was continuously monitored within $60 \mathrm{~min}$ by Beckman Coulter DU800 spectrophotometer.

\subsection{Mass Spectrometry Analysis}

For molecular weight determination of Hsp17.6 that is oxidized by $5 \mathrm{mM} \mathrm{H}_{2} \mathrm{O}_{2}$ or $0.4 \mathrm{mM} \mathrm{HClO}$ in a Tris- $\mathrm{HCl}$ buffer ( $20 \mathrm{mM}$ Tris, $150 \mathrm{mM} \mathrm{NaCl}, 5 \%$ glycerol, $\mathrm{pH} \mathrm{8.0)}$ were analyzed by RP-HPLC-C18-MS using orbitrap fusion (Thermo Fisher Scientific, Massachusetts, MA, USA) after desalting by a Zip Tip 18 pipette tip (Millipore, Burlington, MA, USA). The non-treated Hsp17.6 protein was included as the reference. Protein solutions were desalted using Millipore Zip Tip pipette tips containing C18 reversed-phase media according to the procedure in user guide. Briefly, the tips were wetted with $100 \%$ acetonitrile (ACN) and equilibrated with $0.1 \%$ TFA in Milli-Q grade water. Then protein solutions were loaded on the tips and washed with $0.1 \%$ TFA in Milli-Q grade water to remove the salt. Finally, proteins were eluted using $0.1 \%$ TFA $/ 50 \%$ ACN and completely dried using Speed-vac. The dried protein preparations were dissolved in $0.1 \%$ formic acid (FA) and analyzed with an EASY-nLC 1000 interfaced via a Nanospray Flex ion source to Orbitrap Fusion Tribrid mass spectrometer (Thermo Fisher Scientific). In details, protein samples were loaded onto a trap column (C18, $3 \mu \mathrm{m}$ particles, $100 \mu \mathrm{m}$ inner diameter (ID), $2 \mathrm{~cm}$ length, Dr. Maisch $\mathrm{GmbH})$ and separated using an analytical column $(\mathrm{C} 18,1.9 \mu \mathrm{m}$ particles, $150 \mu \mathrm{m} \mathrm{ID}, 15 \mathrm{~cm}$ length, Dr. Maisch $\mathrm{GmbH}$ ) at a flow rate of $400 \mathrm{~nL} / \mathrm{min}$ with a $30 \mathrm{~min}$ LC gradient composed of Solvent A $(0.1 \%$ formic acid $(v / v))$ and Solvent B (acetonitrile, $0.1 \%$ formic acid $(v / v)$ ) and a gradient elution starting at $20 \%$ to $60 \%$ B for $25 \mathrm{~min}$, from $60-90 \%$ B for $5 \mathrm{~min}$. MS spectra were acquired by orbitrap detector with a resolution of 120,000 and the individual precursor windows were summed across the relevant retention time period where the intact protein elute and then deconvoluted using Xtract tool within Xcalibur Qual Browser.

Protein oxidation status was assayed by LC/MS-MS. The oxidized protein mixtures were separated on a non-reducing SDS-PAGE (12\%) and stained with Coomassie blue R-250. Each protein band was cropped and after twice washing with MS-grade water directly alkylated with $55 \mathrm{mM}$ iodoacetamide (IAM) for $1 \mathrm{~h}$ at $37^{\circ} \mathrm{C}$ in the dark. Then, 
the proteins were in-gel digested overnight using sequencing-grade modified trypsin (Promega, Fitchburg, WI, USA) in $50 \mathrm{mM} \mathrm{NH}_{4} \mathrm{HCO}_{3}$ (pH 8.0) at $37^{\circ} \mathrm{C}$. LC-MS/MS analysis was implemented with the Easy-nLC integrated nano-HPLC system (Proxeon, Odense, Denmark) and Q-Extractive mass spectrometer (Thermo, Waltham, Massachusetts, MA, USA) as described previously [32]. MS/MS spectra were searched against the forward and reverse Hsp17.6 protein sequence (Protein ID: AFV24380) in the NCBI database using the SEQUEST search engine of Proteome Discoverer software (v1.4). The precursor ion mass tolerance was $20 \mathrm{ppm}$ for all MS acquired in an Orbitrap mass analyzer and fragment ion mass tolerance was $0.02 \mathrm{Da}$ for all MS/MS spectra. The search criteria were employed as follows: full tryptic specificity was required; two missed cleavages were allowed; oxidation was used as a variable modification; the false discovery rate (FDR) was set to 0.01 . Triple experiments were performed in parallel.

\subsection{Non-Reducing SDS-PAGE Analysis on Oxidized Proteins}

$\mathrm{MDH}$ in the presence or absence of Hsp17.6 in $15 \mu \mathrm{L}$ PBS $(137 \mathrm{mM} \mathrm{NaCl}, 2.7 \mathrm{mM}$ $\mathrm{KCl}, 10 \mathrm{mM} \mathrm{Na}_{2} \mathrm{HPO}_{4}, 2 \mathrm{mM} \mathrm{KH} \mathrm{PO}_{4}, \mathrm{pH} 7.4$ ), was 30 min-treated by $1 \mathrm{mM} \mathrm{H}_{2} \mathrm{O}_{2}$ or $0-0.8 \mathrm{mM} \mathrm{HClO}$ at $37^{\circ} \mathrm{C}$, and then added to a 4-fold diluted non-reducing SDS loading buffer ( $0.2 \mathrm{M}$ Tris- $\mathrm{HCl}, 40 \%$ glycerol, $8 \%$ SDS, $0.4 \%$ Bromphenol blue, $\mathrm{pH} 6.8$ ). The protein buffer was loaded on $12 \%$ SDS-PAGE gel, and electrophoresed at 150 volts for $1 \mathrm{~h}$, and stained by Coomassie blue R-250. The intensities of the target bands were quantified using ImageJ [33].

\subsection{Western Blot}

A total of $10 \mathrm{~mL}$ of cultures of the sHsps expressed E. coli strains was harvested by centrifuge at $8000 \mathrm{~g}$ for $5 \mathrm{~min}$, resuspended in $400 \mu \mathrm{L}$ PBS and lysed by ultrasonication at $240 \mathrm{~W}$ with a cycle of $3 \mathrm{~s}$ sonication and $3 \mathrm{~s}$ pause for $10 \mathrm{~min}$ on ice. After being quantified by the Pierce BCA Protein Assay Kit (Thermo Fisher Scientific), total proteins of $20 \mu \mathrm{g}$ was electrophoresed on SDS-PAGE under $150 \mathrm{~V}$ for $1 \mathrm{~h}$, and the separated proteins were then transferred to a 0.1-mm nitrocellulose filter membrane (Easybio, Beijing, China) under $380 \mathrm{~mA}$ for $1 \mathrm{~h}$. The membrane was blocked for $1 \mathrm{~h}$ at room temperature using $20 \mathrm{~mL}$ blocking buffer ( $50 \mathrm{~g}$ defatted milk powder, $2.42 \mathrm{~g}$ Tris, $8.0 \mathrm{~g} \mathrm{NaCl}$ in $1 \mathrm{~L}, \mathrm{pH}$ 7.6), and incubated with 1/5000 dilutions of Anti-His-Tag(2A8) mAb (HRP Conjugated) antibody (Abmart, Shanghai, China). The membrane was washed three times with Tris-buffered saline Tween buffer (2.42 g Tris, $8.0 \mathrm{~g} \mathrm{NaCl}, 1 \mathrm{~mL}$ Tween 20 in $1 \mathrm{~L}, \mathrm{pH}$ 7.6), and signals were imaged via a Tanon-5200 Chemiluminescent Imaging System (Tanon Science \& Technology, Shanghai, China).

Supplementary Materials: Supplementary materials can be found at https://www.mdpi.com/1422 $-0067 / 22 / 5 / 2591 / \mathrm{s} 1$.

Author Contributions: Investigation and draft preparation, P.M.; Western blot assays, L.Q.; conceptualization, writing \& editing and funding acquisition, X.D.; Methodology, J.L. All authors have read and agreed to the published version of the manuscript.

Funding: This work is supported by the National Natural Science Foundation of China at Grant nos. 91751203 and 32070061.

Data Availability Statement: The data that support the findings of this study are available from the corresponding author upon reasonable request.

Acknowledgments: The authors thanks Huichun Tong and Lei Qi in assistance of protein oxidation analysis and figure preparation, and Shutao Sun in MS analysis on protein oxidation.

Conflicts of Interest: The authors declare no conflict of interest.

\section{References}

1. Jong, W.W.D.; Caspers, G.J;; Leunissen, J.A.M. Genealogy of The $\alpha$-crystallin-small Heat-shock Protein Superfamily. Int. J. Biol. Macromol. 1998, 22, 162. [CrossRef] 
2. Haslbeck, M. sHsps and Their Role in the Chaperone Network. Cell. Mol. Life Sci. 2002, 59, 1649-1657. [CrossRef] [PubMed]

3. Morris, A.M.; Aquilina, J.A. Evidence for Specific Subunit Distribution and Interactions in the Quaternary Structure of $\alpha$-crystallin. Proteins 2010, 78, 2546-2553. [CrossRef] [PubMed]

4. Waters, E.R.; Lee, G.J.; Vierling, E. Evolution, Structure and Function of the Small Heat Shock Proteins in Plants. J. Exp. Bot. 1996, 47, 325-338. [CrossRef]

5. Boston, R.S.; Viitanen, P.V.; Vierling, E. Molecular Chaperones and Protein Folding in Plants. Plant Mol. Biol. 1996, 32, 191-222. [CrossRef] [PubMed]

6. Swindell, W.R.; Masternak, M.M.; Kopchick, J.J.; Conover, C.A.; Bartke, A.; Miller, R.A. Endocrine Regulation of Heat Shock Protein mRNA Levels in Long-lived Dwarf Mice. Mech. Ageing Dev. 2009, 130, 393-400. [CrossRef]

7. Kalioraki, M.A.; Artemaki, P.I.; Sklirou, A.D.; Kontos, C.K.; Adamopoulos, P.G.; Papadopoulos, I.N.; Trougakos, I.P.; Scorilas, A. Heat Shock Protein Beta 3 (HSPB3) is an Unfavorable Molecular Biomarker in Colorectal Adenocarcinoma. Mol. Carcinog. 2020, 59, 116-125. [CrossRef]

8. Shemetov, A.A.; Seit-Nebi, A.S.; Gusev, N.B. Structure, Properties, and Functions of the Human Small Heat-shock Protein HSP22 (HspB8, H11, E2IG1): A Critical Review. J. Neurosci. Res. 2010, 86, 264-269. [CrossRef] [PubMed]

9. Vos, M.J.; Hageman, J.; Carra, S.; Kampinga, H.H. Structural and Functional Diversities between Members of the Human HSPB, HSPH, HSPA, and DnaJ Chaperone Families. Biochemistry 2008, 47, 7001-7011. [CrossRef] [PubMed]

10. Arrigo, A.P. Small Stress Proteins: Chaperones That Act as Regulators of Intracellular Redox State and Programmed Cell Death. Biol. Chem. 1998, 379, 19-26. [PubMed]

11. Carra, S.; Alberti, S.; Arrigo, P.A.; Benesch, J.L.; Benjamin, I.J.; Boelens, W.; Bartelt-Kirbach, B.; Brundel, B.J.J.M.; Buchner, J.; Bukau, B.; et al. The Growing World of Small Heat Shock Proteins: From Structure to Functions. Cell Stress Chaperones 2017, 22, 601-611. [CrossRef] [PubMed]

12. Kandror, O.; Goldberg, A.L. Trigger Factor is Induced upon Cold Shock and Enhances Viability of Escherichia coli at Low Temperatures. Proc. Natl. Acad. Sci. USA 1997, 94, 4978-4981. [CrossRef]

13. Manuel, F.; Chernikova, T.N.; Yakimov, M.M.; Golyshin, P.N.; Timmis, K.N. Chaperonins Govern Growth of Escherichia coli at Low Temperatures. Nat. Biotechnol. 2003, 21, 1266-1267.

14. Matuszewska, E.; Kwiatkowska, J.; Kuczynska-Wisnik, D.; Laskowska, E. Escherichia coli Heat-shock Proteins IbpA/B are Involved in Resistance to Oxidative Stress Induced by Copper. Microbiology 2008, 154, 1739-1747. [CrossRef] [PubMed]

15. Sakthivel, K.; Watanabe, T.; Nakamoto, H. A Small Heat-shock Protein Confers Stress Tolerance and Stabilizes Thylakoid Membrane Proteins in Cyanobacteria Under Oxidative Stress. Arch. Microbiol. 2009, 191, 319-328. [CrossRef]

16. Saji, H.; Iizuka, R.; Yoshida, T.; Abe, T.; Kidokoro, S.I.; Ishii, N.; Yohda, M. Role of the IXI/V Motif in Oligomer Assembly and Function of StHsp14.0, a Small Heat Shock Protein from the Acidother-mophilic archaeon, Sulfolobus tokodaii Strain 7. Proteins 2008, 71, 771-782. [CrossRef]

17. Abe, T.; Oka, T.; Nakagome, A.; Tsukada, Y.; Yasunaga, T.; Yohda, M. StHsp14.0, a Small Heat Shock Protein of Sulfolobus tokodaii Strain 7, Protects Denatured Proteins from Aggregation in the Partially Dissociated Conformation. J. Biochem. 2011, 150, 403-409. [CrossRef] [PubMed]

18. Kim, R.; Kim, K.K.; Yokota, H.; Kim, S.-H. Small Heat Shock Protein of Methanococcus jannaschii, A Hyperthermophile. Proc. Natl. Acad. Sci. USA 1998, 95, 9129-9133. [CrossRef] [PubMed]

19. Haslbeck, M.; Kastenmüller, A.; Buchner, J.; Weinkauf, S.; Braun, N. Structural Dynamics of Archaeal Small Heat Shock Proteins. J. Mol. Biol. 2008, 378, 362-374. [CrossRef]

20. Zhang, G.; Jiang, N.; Liu, X.; Dong, X. Methanogenesis from Methanol at Low Temperatures by a Novel Psychrophilic Methanogen, "Methanolobus psychrophilus" sp. nov., Prevalent in Zoige Wetland of the Tibetan Plateau. Appl. Environ. Microbiol. 2008, 74, 6114-6120. [PubMed]

21. Chen, Z.; Yu, H.; Li, L.; Hu, S.; Dong, X. The Genome and Transcriptome of a Newly Described Psychrophilic Archaeon, Methanolobus psychrophilus R15, Reveal its Cold Adaptive Characteristics. Environ. Microbiol. Rep. 2012, 4, 633-641. [PubMed]

22. Li, J.; Qi, L.; Guo, Y.; Yue, L.; Li, Y.; Ge, W.; Wu, J.; Shi, W.; Dong, X. Global Mapping Transcriptional Start Sites Revealed Both Transcriptional and Post-transcriptional Regulation of Cold Adaptation in the Methanogenic Archaeon Methanolobus psychrophilus. Sci. Rep. 2015, 5, 9209. [CrossRef]

23. Nyström, T. Stationary-phase Physiology. Annu. Rev. Microbiol. 2004, 58, 161-181. [CrossRef] [PubMed]

24. Terman, A. Garbage Catastrophe Theory of Aging: Imperfect Removal of Oxidative Damage? Redox Rep. 2001, 6, 15-26. [CrossRef]

25. Dahl, J.-U.; Gray, M.J.; Jakob, U. Protein Quality Control under Oxidative Stress Conditions. J. Mol. Biol. 2015, 427, 1549-1563. [CrossRef]

26. Belousov, V.V.; Fradkov, A.F.; Lukyanov, K.A.; Staroverov, D.B.; Shakhbazov, K.S.; Terskikh, A.V.; Lukyanov, S. Genetically Encoded Fluorescent Indicator for Intracellular Hydrogen Peroxide. Nat. Methods 2006, 3, 281-286. [CrossRef] [PubMed]

27. Weiss, R.F. The Solubility of Nitrogen, Oxygen and Argon in Water and Seawater. Deep Sea Res. 1970, 17, 721-735. [CrossRef]

28. Winter, J.; Ilbert, M.; Graf, P.; Özcelik, D.; Jakob, U. Bleach Activates a Redox-regulated Chaperone by Oxidative Protein Unfolding. Cell 2008, 135, 691-701. [CrossRef]

29. Jakob, U. Redox Switch of Hsp33 Has a Novel Zinc-binding Motif. J. Biol. Chem. 2000, 275, 38302-38310. [CrossRef] [PubMed]

30. Varrone, S.; Consiglio, E.; Covelli, I. The Nature of Inhibition of Mitochondrial Malate Dehydrogenase by Thyroxine, Iodine Cyanide and Molecular iodine. Eur. J. Biochem. 2010, 13, 305-312. [CrossRef] [PubMed] 
31. Xican, L. Improved Pyrogallol Autoxidation Method: A Reliable and Cheap Superoxide-scavenging Assay Suitable for all Antioxidants. J. Agric. Food Chem. 2012, 60, 6418-6424.

32. Chen, Z.; Wang, X.; Yang, F.; Hu, Q.; Tong, H.; Dong, X. Molecular Insights into Hydrogen Peroxide-sensing Mechanism of the Metalloregulator MntR in Controlling Bacterial Resistance to Oxidative Stresses. J. Biol. Chem. 2017, 292, 5519-5531. [CrossRef] [PubMed]

33. Schindelin, J.; Arganda-Carreras, I.; Frise, E.; Kaynig, V.; Longair, M.; Pietzsch, T.; Preibisch, S.; Rueden, C.; Saalfeld, S.; Schmid, B.; et al. Fiji: An Open-source Platform for Biological-image Analysis. Nat. Methods 2012, 9, 676-682. [CrossRef] [PubMed] 